\title{
KESENJANGAN ANTARA ACUAN YURIDIS NORMATIF DAN KENYATAAN SOSIAL DALAM PERLINDUNGAN HUKUM TERHADAP PEKERJA MIGRAN
}

\author{
Rr. Ani Wijayati*
}

\begin{abstract}
Legal protection of migrant workers in Indonesia are spread in many legal instrument including national laws, international convention and diplomatic agreements but there is not law or regulation that specifically regulates and recognizes the existence of formal implement homework that implicates protect.UU.No.39 Tahun 2004 was not sufficient to provide protection and acces. At the level of policy or implementation of this legislation is positioned migrant workers as a commodity in the form of provision of cheap labor for employers and not the protection of migrant workers
\end{abstract}

\section{Kata Kunci : Acuan yuridis, perlindungan hukum, buruh migran}

\section{Pendahukuan}

Kondisi yang memprihatinkan atas kehidupan sosial masyarakat dapat dilihat dari besarnya angka pengangguran di Indonesia. Pusat Data Informasi (Pusdatin) Kementerian Tenaga Kerja dan Transmigrasi (Kemenakertrans) RI mencatat ada 22.753 angka pengangguran terbuka di tahun $2005 .{ }^{1}$ Tahun 2008 jumlah menjadi 18.822 .105 orang dan 9.258 .964 orang berstatus sebagai pengangguran terbuka hingga bulan Februari 2009. Angka pengangguran terbuka di Indonesia memang terus turun hingga 8.12 persen pada Mei $2011^{2}$ jumlah angka tersebut memberi gambaran nyata bahwa jumlah pencari kerja di Indonesia masih sangat besar dan belum diimbangi dengan kerja yang luas. Faktor lapangan kerja yang sempit dan kebutuhan ekonomi yang mendesak menyebabkan minat sebagian besar masyarakat Indonesia untuk melakukan migrasi dan bekerja di luar negeri sebagai pekerja migran Indonesia. Selama rentang waktu

\footnotetext{
* Dosen Tetap FH UKI

1. Pengangguran terbuka didefinisikan oleh SAKERNAS (Survei Tenaga Kerja Nasional) sebagai orang yang sedang mencari pekerjaan atau yang sedang mempersiapkan usaha atau juga yang tidak mencari pekerjaan, karena merasa tidak mungkin lagi mendapatkan pekerjaan, termasuk juga mereka yang baru mendapat kerja tetapi belum mulai bekerja. Pengangguran terbuka tidak termasuk orang yang masih sekolah atau mengurus rumah tangga, sehingga hanya orang yang termasuk angkatan kerja saja yang merupakan pengangguran terbuka. Disadur dari www.sakernas.blogspot.com pada tanggal 20 Oktober 2014 pukul 03,30 WIB.

${ }^{2}$ Berdasarkan Data dan Informasi Penempatan Tenaga Kerja, Pusat Data dan Ketenagakerjaan, Badan Penelitian, Pengembangan dan Informasi, Kementerian Tenaga Kerja dan Transmigrasi RI, 2011, h 42
}

tahun 2005 sampai 2014, pengiriman buruh migran di Indonesia ke hampir negara penempatan (negara tujuan), didominasi oleh perempuan dan mayoritas mereka bekerja di sektor informal, seperti pekerja rumah tangga (PRT), baby sitter dan perawat lanjut usia (manula). Badan Nasional Penempatan dan Perlindungan Tenaga Kerja Indonesia (BNP2TKI) mencatat pekerja migran perempuan memang lebih dominan dibanding buruh migran laki-laki selama rentang waktu tersebut.

Data tersebut semakin menguatkan buruh migran Indonesia khususnya perempuan, berkontribusi besar terhadap laju ekonomi negara ${ }^{3}$. Perempuan yang pada awalnya tersingkir dari kerja perladangan untuk kemudian digantikan dengan teknologi modern dan dikenal peristiwa "green revolution", harus mencari penghidupan yang lain. Feminisasi kemiskinan dan konsep patriarkhal pun terjadi di sektor kerja domestik, mendapat upah yang murah dengan perlindungan yang minim.

Negara yang banyak merekrut PRT migran serta sektor informal lainnya bagi perempuan ialah Malaysia. Malaysia menjadi salah satu tujuan utama bagi mayoritas buruh migran perempuan Indonesia dengan beberapa pertimbangan. ${ }^{4}$ Pertama, negara

\footnotetext{
${ }^{3}$ Negara sangat diuntungkan dengan pengiriman buruh migran Indonesia ke beberapa negara pemasok. Berdasarkan catatan yang ditulis oleh Pusat Data dan Informasi ketenagakerjaan empat tahun belakangan yaitu 2004-2007, TKI menyumbang US\$ 13.87 miliar.

${ }^{4}$ Ana Sabhana Azny, Negara dan Buruh Migran Perempuan, 2012, Jakarta:Yayasan Pustaka Obor Indonesia, h. 5.
} 
yang mulai bangkit dan menggeliat sektor perekonomiannya ini, jelas membutuhkan banyak tenagakerja yang pada akhirnya menarik perempuan Malaysia untuk turut serta bekerja pada sektor publik. Sektor rumah tangga yang kosong tentu membutuhkan jasa tenaga kerja untuk membereskan segala tugas rumah tangga dan menjaga anak-anak sang majikan. Lapangan kerja yang minim di dalam negeri, membuat minat banyak warga Indonesia kemudian mendaftar bekerja di Malaysia. Pemerintah Malaysia pun akhirnya membuat kebijakan menarik tenaga kerja dari Indonesia. Kedua, kondisi ekonomi Negara Malaysia yang lebih baik dibanding jika bekerja di Indonesia, terlebih dalam sektor yang sangat dibutuhkan dan berisiko, seperti PRT. Pengupahan yang tinggi untuk kerja yang sama jika di dalam negeri menjadi daya tarik dan daya dorong bagi mayoritas warga yang ingin bekerja mendapatkan uang. Ketiga, kemudian bahasa yang digunakan, yaitu Melayu membuat warga Indonesia tidak terlalu sulit memahami dan mempelajari bahasa yang digunakan. Malaysia sebagai tujuan utama bagi pencari kerja di Indonesia.

Negara Arab Saudi merupakan negara kedua terbanyak pekerja migran Indonesia. Faktor-faktor penarik yang menjelaskan adanya permintaan perempuan pekerja migran di Timur Tengah termasuk Arab Saudi adalah sebagai berikut: ${ }^{5}$

1. Booming minyak dekade 1970 an telah meningkatkan standar hidup orang Arab, lebih banyak keluarga muda cenderung tinggal jauh dari keluarga besar mereka, dan mereka mampu mempekerjakan pekerja domestik dengan bayaran murah;

2. Pekerja domestik mengambil alih tanggung jawab rumah tangga perempuan Arab di sana, dan ini memberikan lebih banyak waktu kepada mereka untuk dapat beraktivitas sosial.

3. Mempekerjakan pekerja domestik dari luar negeri berarti mengangkat antara sosial dan prestise keluarga.

Sesungguhnya, baik pemerintah Malaysi, Arab Saudi maupun Indonesia mempunyai hubungan simbiosis mutualisme dalam arus migrasi tenaga kerja tersebut. Warga Malaysia dan Arab Saudi terbantu dengan tenaga kerja dari Indonesia untuk segala jenis

\footnotetext{
${ }^{5}$ Sulistyowati Irianto, Akses Keadilan dan Migrasi Global, Jakarta: Yayasan Pustaka Obor Indonesia,, 2011, h 21
}

bidang kerja terlebih PRT dan pemerintah Indonesia dapat menekan angka pengangguran di dalam negeri, karena tidak tersedianya lapangan kerja yang mumpuni. Namun sayangnya hubungan saling menguntungkan tersebut tidak diiringi dengan perlindungan yang berkualitas, baik sejak masa sebelum penempatan (pra penempatan), ketika bekerja di luar negeri (masa penempatan) hingga kembali ke Negara Indonesia (purna penempatan).

Beberapa potret kasus kekerasan yang terjadi pada buruh migran perempuan Indonesia sektor informal yang bekerja di Malaysia dan Arab Saudi dapat dilihat secara jelas mulai dari tahun 2004, dimana media massa gencar memberitahukan tentang penganiayaan yang dialami oleh Nirmala Bonat, seorang PRT migran yang bekerja di Malaysia. Ia mengalami penyiksaan dari majikannya berupa penyiraman air panas, bekas seterika pada badannya, pemukulan kepada dengan gantungan baju oleh majikannya ${ }^{6}$. Meskipun demikian, bukan berarti bahwa kejadian penganiayaan terhadap buruh migran perempuan Indonesia baru terjadi di tahun $2004 .^{7}$ Sudah banyak terjadi penganiyaan, namun tidak diketahui oleh masyarakat Indonesia. Kasus tindakan kekerasan terhadap buruh migran perempuan menjadi pembicaraan khalayak dan mulai terekspos secara ramai di media, karena pada tahun itulah Indonesia mempunyai Undang-undang Nomor 39 Tahun 2004 tentang Penempatan dan Perlindungan TKI di Luar Negeri (PPTKILN).

Pada umumnya payung perlindungan hukum terhadap buruh migran di Indonesia tersebar dalam banyak instrumen hukum, termasuk hukum nasional, konvensi internasional dan persetujuan diplomatik, namun tidak ada hukum atau regulasi yang secara khusus mengatur dan mengakui keberadaan pekerjaan rumah tangga sebagai pekerjaan formal yang berimplikasi melindungi pekerjaannya.

\section{Permasalahan}

Bagaimanakah perlindungan hukum terhadap pekerja migran serta kaitannya dengan perubahan sosial.

\footnotetext{
${ }^{6} \mathrm{Hal}$ ini berlawanan dengan situasi perempuan pekerja migran di Hongkong dan Taiwan tempat mereka bekerja memberikan upah yang layak dan hak-haknya dilindungi.

${ }^{7}$ http://nasional.vivanews.com/news/read/6 of 973-Siti Hajar Senasib dengan Nirmala Bonar diakses pada tanggal 21 Februari 2014.
} 


\section{Tujuan Penulisan}

Untuk mengetahui bagaimanakah sebenarnya perlindungan hukum terhadap pekerja migran kaitannya dengan perubahan sosial

\section{Penyebab Migrasi}

Setiap individu berhak untuk bebas berpindah dan bermigrasi untuk memperoleh kehidupan yang lebih baik. Saat ini jutaan orang menjadi bagian dari gelombang migrasi global yang dinamis, dari dan ke segala penjuru dunia. Migrasi, telah menyebabkan dunia kehilangan batas-batas konvensionalnya. ${ }^{8} \mathrm{Ge}-$ lombang migrasi telah menepis batas-batas negara, hukum dan bahkan budaya. Batas negara hanyalah batas administratif dan hukum kehilangan batas yuridiksi substantifnya.

Migrasi telah menyebabkan pertemuan antar kebudayaan yang menghasilkan kebudayaan massal, kebudayaan global. Di seluruh dunia dapat ditemui adanya unsur kebudayaan global yang sangat terdukung oleh pertukaran uang dan jasa yang luar biasa kuatnya dan teknologi informasi yang begitu agresif. Kebudayaan global hidup berdampingan dengan kebudayaan tradisional.

Ada banyak sebab mengapa orang melakukan migrasi, yang terbesar adalah karena pekerjaan dalam rangka penghidupan yang lebih layak. Migrasi karena pekerjaan merupakan situasi yang paling umum, karena dapat dijumpai di berbagai belahan dunia. Masyarakat dan kelompok paling miskin di negara berkembang bermigrasi ke negara-negara yang lebih kaya. Pada umumnya mereka mengisi lowongan pekerjaan rendah, dengan upah rendah dan kondisi kerja yang buruk, karena ketiadaan perlindungan hukum. Kebanyakan dari pekerjaan migran yang mengisi pekerjaan rendah dan dalam skala masif ini adalah perempuan. Teori migrasi dan ideologi gender yang mengatakan bahwa perempuan hanya bekerja tak jauh dari tinggalnya ternyata dalam konteksi ini tidak lagi berlaku. ${ }^{9}$

Globalisasi ekonomi dunia telah mengubah pola perburuhan dan perdagangan di seluruh dunia. Trend yang berkembang adalah menuju perdagangan bebas,

\footnotetext{
${ }^{8}$ Rachmat Syafaat, Dagang Manusia: Kajian Trafficching terhadap Perempuan dan Anak, Yogyakarta: Lappera Pustaka Utama, 2003, h.9.

${ }^{9}$ Ridjal. Dinamika Gerakan Perempuan di Indonesia, Yogyakarta: Tiara Wacana, 1993,.h.10.
}

sebagai realisasi dari kesepakatan GATT (General Agreement of Tarif and Trade) yang telah ditandatangani negara anggotanya di Marakesh tahun 1994. Kondisi ini membuka peluang lebih terbukanya lalu lintas arus barang, jasa dan tenaga kerja. Banyak tenaga kerja bermigrasi dari daerah miskin ke daerah atau negara lain yang lebih kaya dan menjanjikan hidup yang lebih layak. ${ }^{10}$

Fenomena globalisasi terjadi melalui proses sejarah yang panjang sejak revolusi industri di Inggris. Terbentuknya prinsip, struktur dan mekanisme migrasi ke dalam pola yang mantap memerlukan waktu lima abad lebih. Penyederhanaannya dikonstruksi ketika era developmentalisme berakhir, yaitu pada akhir abad ke-20 dan awal abad ke-21 dan mulai tampak nyata pada pasca perang dingin 1989. Proses pengintegrasian ekonomi nasional ke dalam sistem ekonomi dunia terjadi karena keyakinan pada perdagangan bebas yang sesungguhnya telah dicanangkan sejak masa kolonial. Dalam hal ini dapat dibaca bahwa terjadi perpindahan kontrol dari pengaruh atas masalah ekonomi dari tingkat lokal nasional ke tingkat global. ${ }^{11}$

Sejarah globalisasi ditandai oleh sejarah dominasi dan eksploitasi manusia atau manusia yang dilalui mulai dari periode kolonialisme, era neo-liberalisme dan era globalisasi. Globalisasi menyiratkan penataan ulang secara mendasar tentang dinamika kultural dalam waktu dan ruang. Globalisasi adalah masa yang tak terelakkan oleh banyak negara dan bangsa. Tak satupun negara di dunia ini yang mampu bertahan dengan komunitas monolitiknya.

Globalisasi telah melahirkan migrasi. Industri migrasi mempengaruhi kebijakan negara dan telah melibatkan begitu banyak pihak yang mencari kehidupan di dalamnya. Mereka menjadi agen-agen penting dalam mengorganisir keberlangsungan migrasi itu seperti perekrut tenaga kerja, para calo, biro perjalanan dan agen perumahan. Selain itu, ada para pengacara yang memberikan berbagai jasa berkaitan dengan undangundang migrasi, bisnis bank menjadi bagian penting dengan memberikan layanan fasilitas transfer khusus untuk mengatur pengiriman remitasi.

Globalisasi tidak lagi dapat diartikan sebagai perjalanan satu arah dari Barat ke Timur melalui penye-

\footnotetext{
${ }^{10}$ Guy Standing, Global Labour Flexibility, Seeking Distributive Justice, London :Macmilan Press, 1999, h.25

${ }^{11}$ Rosaldo Renato dan Inda J. The Antropology of Globalisazations a Reader, Oxford: Blackwell Publishers, 2002, h.37
} 
baran nilai dan konsep demokrasi, hak asasi manusia beserta instrument hukumnya. Globalissi adalah juga persebaran nilai, konsep dan hukum dari berbagai penjuru dunia menuju berbagai penjuru dunia. Globalisasi tidak hanya diindikasikan oleh borderless states tetapi tetapi juga borderless law. Hukum dari wilayah tertentu dapat menembus ke wilayah-wilayah lain yang tanpa batas. Hukum internasional dan transaksional dapat menembus ke wilayah negara-negara manapun bahkan wilayah lokal ${ }^{12}$ yang manapun di akar rumput. Atau sebaliknya bukan hal yang mustahil bila hukum dan prinsip-prinsip lokal diadopsi sebagian atau seluruhnya menjadi hukum berskala internasional.

Di pihak lain, pertemuan antara berbagai sistem hukum dapat juga ditunjukkan dari adanya hukum nasional yang mengadopsi substansi traktat internasional, khususnya dalam bidang humanitarian. Ideide mengenai keadilan dari berbagai penjuru dunia, lokal, dapat menjadi bagian dari instrumen hukum internasional yang dirumuskan secara bersama oleh banyak delegasi negara dan mengikat bagi negaranegara yang meratifikasinya. Sebagai contoh adalah Kovensi CEDAW (Konvensi Penghapusan Segala Bentuk Diskriminasi terhadap Wanita). ${ }^{13}$

Pada dasawarsa terakhir keberadaan perempuan sebagai bagian dari kelompok yang termarjinalkan yang kurang mendapatkan akses keadilan. Hal ini bukan disebabkan seksualitas mereka semata sebagai perempuan, tetapi lebih rumit karena perempuan ditempatkan dalam relasi internasional terkait ras, kelas, kolonialisme dan naturisme. ${ }^{14}$

Di dalam struktur masyarakat Indonesia dan dunia pada umumnya terdapat kesenjangan antara status (hak dan kewajiban) serta peran pria dan perempuan yang disebabkan oleh sistem patriarkhi yang melanggengkan superioritas pria. Keadaan demikian tambah diperkuat oleh sistem kapitalisme yang telah mendunia dan telah membudaya serta diinternalisasi masyarakat pada umumnya, bermilenium lamanya. Dalam bidang hukum, pemarginalisasi perempuan dari hak memiliki, mengakses, menikmati dan mengontrol

\footnotetext{
12 Lokal dalam arti ruang dan konteks sosio politik tertentu.

${ }^{13}$ CEDAW disingkat dari naskah aslinya "Convention on the Elemination of All Discrimination Against Women. Periksa L.M.Gandhi Lapian, Disiplin Hukum yang Mewujudkan Kesetaraan dan Keadilan Gender, Jakarta : Pustaka Obor Indonesia, 2012, h.1.

${ }^{14}$ Henrieta Moore, Feminism and Antropology, University of Minnesota, 1998, h.75.
}

atas harga keluarga atau harta benda perkawinan seperti tanah, rumah dan penghasilan serta sumber non material seperti waktu untuk mengembangkan diri sendiri, partisipasi dalam bidang politik.

Dewasa ini masyarakat mulai menyadari bahwa ketidaksetaraan status dan kedudukan laki-laki dan perempuan serta masyarakat hukum, merupakan kenyataan yang bukan hanya ditentukan secara biologis atau kodrati, tetapi lebih banyak secara sosial. Disadari pula bahwa ketidaksetaraan gender yang terkondisi secara sosial, tentunya harus dapat diubah baik dalam tingkat individual maupun dalam kepatutan (equity) dan kesetaraan serta kemitraan antara laki-laki dan perempuan. ${ }^{15}$

Hukum sebagai lembaga telah berabad lamanya ikut melanggengkan dominasi laki-laki serta sub ordinasi perempuan dalam masyarakat. Ungkapan Von Savigny bahwa hukum itu tumbuh dan berkembang dalam haribaan masyarakat dalam kenyataan memang ada benarnya dan jika hukum yang didiskriminatif sudah terinternalisasi selama berabad-abad maka hukum itu telah menjadi gunung es yang membatu. Oleh karena itu jika tujuannya untuk menghukum transformasi, reformasi dan mengubah keadaan maka perlu dikaji dan dipahami bagaimana status perempuan dalam hukum itu, bagaimana persepsi pembentuk dan penafsir norma hukum tersebut terhadap perempuan dan bagaimana dampaknya terhadap harkat, martabat dan hak perempuan. Karena pada saat yang sama dengan harapan mengenai hukum sebagai gunung es yang membeku ada ungkapan Roscoe Pound ${ }^{16}$ yang juga benar, apalagi dewasa ini yaitu bahwa hukum merupakan alat untuk mengubah (merekayasa) masyarakat. Jika posisi ketidakadilan terhadap perempuan hendak direformasi, maka hukum merupakan alat atau sarana yang harus digunakan. Untuk itu perlu adanya pemahaman mengenai struktur dan dampak peraturan dan norma hukum.

\section{Hukum dan Budaya}

Pekerjaan domestik adalah pekerjaan tertua dan paling penting yang dilakukan oleh mayoritas perem-

\footnotetext{
${ }^{15}$ Dalam Sosialisasi mengenai konvensi CEDAW sering dihabiskan waktu untuk membicarakan apakah sebaiknya menggunakan kata perempuan atau wanita dan pria atau laki-laki. Undang-undang menggunakan kata pria dan wanita, ada yang memilih kata laki-laki dan perempuan.

${ }^{16}$ Yesmil Anwar dan Adang, Pengantar Sosiologi Hukum, Jakarta: Grasindo, 2008, h.143
} 
puan, dan sepanjang sejarah sangat terkait dengan perbudakan kolonial. Dalam dekade terakhir ini dapat disaksikan bahwa pekerjaan domestik merupakan gelombang migrasi yang bersifat masif dan global. Permintaan akan tenaga kerja migran domestik memacu para perempuan yang tidak memiliki pendidikan dan keterampilan cukup, pergi meninggalkan tanah kelahirannya di negara-negara dunia ke tiga ke negaranegara lebih kaya. Migrasi perempuan menciptakan pekerjaan domestik di luar negeri yang membentuk rumah tangga transnasional. Mata rantai global yang diciptakan sangat luas dan rumit, banyak melibatkan banyak faktor baik secara individual maupun kelembagaan. Pekerjaan ini juga menciptakan lalu lintas yang dalam jumlah yang luar biasa dari suatu negara ke negara lain, dan menghidupi banyak orang yang terlibat di dalamnya. ${ }^{17}$

Tidak mudah untuk mendefinisikan hakekat dari pekerjaan (migran) domestik, karena keragaman perspektif kultural. Setiap budaya masyarakat dan bangsa memiliki pemaknaan sendiri tentang pekerjaan yang digolongkan sebagai "care work in the house hold" atau "labour of love" ini. ${ }^{18}$ Pemaknaan ini berimplikasi pada terabaikannya keberadaan pekerjaan domestik dari hukum. Pengalaman perempuan pekerja migran domestik di luar negeri tidak diperhitungkan oleh hukum. Beberapa Negara dalam survey ILO tidak mengatur keberadaan pekerja migran domestik, mereka hanya mengatur soal perluasan pekerjaan domestik ketika pekerjaan itu bersentuhan dengan pekerjaan di pasar kerja. Dengan demikian lingkup pekerjaan domestik yang dapat diidentifikasi adalah beberapa atribut saja. ${ }^{19}$

Dari perspektif akses keadilan, salah satu ciri penting dari pekerjaan (migran) domestik adalah pertama tidak ada hukum yang mengatur secara khusus. Ketiadaan hukum itu terkait dengan bagaimanakah pekerja migran domestik, yang pada umumnya perempuan itu, diproyeksikan oleh hukum, yang pada umumnya perempuan itu, diproyeksikan oleh hukum. Pekerjaan rumah tangga dianggap bukan pekerjaan

\footnotetext{
${ }^{17}$ Kurnia Novianti, Analisis Dan Dampak Pengiriman TKI: Kasus Dua Desa Di Lombok Timur, Nusa Tenggara Barat, Jurnal LIPI vol.V No.1, 2010, Jakarta, h. 124

${ }^{18}$ Sulistyowati Irianto, op cit, h. 39

${ }^{19}$ ILPO Geneva, 2010, Decent Work for domestic workers, mengidentifikasi beberapa peraturan di negara-negara tertentu yang bersentuhan dengan pekerjaan domestik: "Generally speaking of fundamental criteria of domestic work is that it takes place in the "hoursehold"
}

atau hanyalah pekerjaan informal, pekerjaan tambahan bagi perempuan dan tergolong pekerjaan kotor. Ada kesan bahwa pekerjaan ini bukanlah pekerjaan yang pantas dimasukkan ke dalam pasar kerja dalam keluarga. Pandangan rendah terhadap pekerjaan rumah tangga ini besar implikasinya, yaitu tidak memiliki status yang jelas dalam legislasi perburuhan modern, dan diabaikan dalam hukum formal dan penegakannya. ${ }^{20}$

Karena tidak diatur dalam hukum negara formal, maka aturan yang sangat dominan berkenaan dengan keberadaan pekerja migran domestik dan pekerjaannya adalah aturan yang diciptakan dalam rumah tangga dimana dia bekerja. Tentu saja aturan ini menjadi sangat bervariasi berdasarkan budaya dari negara di tempat majikan. Hal inilah yang menyebabkan awal dari banyak tragedi kemanusiaan yang tidak terbayangkan di kalangan para pekerjaan domestik yang bekerja di luar negeri.

Ciri yang kedua adalah dunia kerja berada di dalam rumah "The home in the work place". Jutaan rumah tangga di seluruh dunia merupakan tempat kerja bagi para pekerja domestik. Mereka dianggap sebagai salah satu anggota dalam keluarga. ${ }^{21}$

"The work in households, which are not considered workplace and they work for private persons, who are not considered employers. In addition, private homes are not usually by labour inspection since labour inspection are forbidden from visiting private household".

Mereka dibayar karena mengerjakan pekerjaanpekerjaan keluarga yang cakupannya sangat luas. Hampir semua pekerjaan di dalam rumah yang berawalan me: mencuci, memasak, menyeterika, mengepel, menyapu, merawat orangtua, mengasuh anak, bahkan kadang binatang rumah. Sebagai pekerja "care work in the household" dan "labour of love" (ILO, 2010) di dalam pekerjaan itu terdapat rincian yang tidak terbatas. Skema berikut ini memperlihatkan beberapa pekerjaan domestik dalam rincian yang cukup luas.

\footnotetext{
${ }^{20}$ Hanya sedikit negara yang memiliki Undang-undang khusus yang memberi perlindungan terhadap pekerja domestik di negaranya sendiri seperti Afrika Selatan, Filipina dan Hongkong. Remirez Machado menemukan hanya 19 negara yang memilik ketentuan khusus tentang pekerja domestik, itupun terintegrasi dalam undang-undang ketenagakerjaan pada umumnya.

${ }^{21}$ Program Studi Kajian Wanita, Universitas Indonesia, Perempuan dan Pemberdayaan, Jakarta, 1997 h. 195.
} 
ILO mendefinisikan Pekerjaan Domestik berdasarkan beberapa ketentuan di berbagai negara.

1. Klasifikasi ditujukan kepada pekerjaan komersial, institusi dan rumah tangga pribadi. Klasifikasi ini meliputi dua kategori, yaitu pertama adalah kerumahtanggaan, yang meliputi pekerja rumah tangga dan pekerja yang berhubungan dengan kerumahtanggaan dan tukang masak. Kedua adalah pekerja perawatan personal dan yang berkaitan, termasuk pengasuh anak, dan pekerja yang melakukan perawatan personal di dalam rumah.

2. Klasifikasi ditujukan kepada pekerja pengasuh anak yaitu mereka yang mengasuh anak majikan dan mengawasi aktivitas keseharian, dan meliputi pekerjaan:

a. Membantu anak-anak untuk mandi,memakai pakaian dan makan sendiri.

b. Membawa anak-anak ke dan dari sekolah dan rekreasi di luar rumah.

c. Bermain dengan anak-anak atau menghiburnya dengan membaca atau mendongeng.

d. Memelihara tata tertib di kamar tidur dan kamar bermain anak-anak.

e. Mengasuh anak sekolah ketika makan siang atau istirahat sekolah.

f. Mengasuh anak sekolah dalam ekskursi atau kunjungan ke musium atau kunjungan lain.

g. Mengerjakan pekerjaan yang lain.

h. Mengawasi pekerja yang lain.

3. Pekerja perawat personal di dalam rumah yang hadir untuk berbagai kebutuhan personal yang pada umumnya menyediakan pemeliharaan personal untuk orang-orang yang membutuhkannya di dalam rumah mereka sendiri karena sakit fisik dan mental atau kecacatan karena usia tua. Tugas dalam kategori ini adalah bantuan perawatan di rumah, yang meliputi:

a. Membantu orang pergi atau bangun dari tempat tidur dan berganti pakaian.

b. Mengganti sprei tempat tidur dan membantu orang untuk mandi

c. Menyediakan makanan disediakan oleh mereka atau orang lain dan memberi makan orang yang membutuhkan.

d. Memberi atau memastikan bahwa orang menelan obat-obat yang dibutuhkan.

e. Mengawasi setiap tanda kemunduran dalam kesehatan seseorang dan menginformasikan- nya kepada dokter yang relevan dan pekerja sosial.

f. Melakukan pekerjaan yang saling berhubungan

g. Mengawasi pekerja-pekerja lain

4. Klasifikasi yang mengacu secara khusus kepada pekerja domestik dan pembantu yang terkait, pembersih dan pencuci. Kategori ini meliputi rumah tangga privat, hotel, kantor, rumah sakit dan lembaga lain, termasuk juga pekerjaan membersihkan interior dan peralatan. Kategori ini meliputi pekerja domestik, pembersih, dan pencuci pakaian dengan tangan.

5. Klasifikasi lain adalah pekerja domestik dan pembersih yang meliputi menyapu, menyedot debu, mencuci dan menyemir, mengganti sprei, membeli alat-alat rumah tangga, menyiapkan makanan, menyediakan hidangan dan melakukan berbagai pekerjaan domestik lainnya.

Ciri ketiga karena berada di dalam rumah tangga dan dalam rincian tugas yang tidak terbatas, maka pekerjaan itu dilakukan dalam waktu yang panjang melebihi jam kerja dalam sektor formal. Dalam berbagai laporan badan dunia dan Lembaga Swadaya Masyarakat Indonesia, diketahui bahwa salah satu problem serius yang dihadapi adalah jam kerja yang terlalu panjang, ditambah lagi ketiadaaan waktu libur dalam seminggu (kecuali Hongkong). ${ }^{22}$

Ciri keempat, karena dianggap sebagai pekerja rendah, maka bila pekerjaan ini menjadi pekerjaan yang dibayar, bayarannya tidak sebanding dengan pekerjaan di pasar kerja. Tidak ada hukum yang jelas yang memberi standar berapa kelayakan upah yang harus diterima oleh pekerja domestik sesuai dengan bobot pekerjaan dan risikonya. Ada bukti juga yang menunjukkan bahwa terjadi diskriminasi upah berdasarkan gender dan nasionaliti dari para pekerja migran domestik. Di beberapa tempat, pekerja mendapat upah lebih baik daripada sesamanya, yang dihubungkan juga pendidikan dan kompetensi pengalaman. Di Malaysia, misalnya pekerja dari Filipina mendapat upah lebih baik dari pekerja dari Indonesia.

\footnotetext{
${ }^{22}$ KOPBUMI, Legal Analisis UU No.39 Tahun 2004 tentang Penempatan dan Perlindungan Tenaga Kerja Indonesia. Jakarta, 2005, h.7
} 
Masalah lain yang juga muncul dalam soal pengupahan adalah keterlambatan upah dan upah yang tidak dibayar. Belum lagi bagi perempuan pekerja migran domestik Indonesia, upah mereka harus dipotong untuk biaya yang tidak mereka ketahui. ${ }^{23}$

Ciri kelima karena hampir tidak ada perlindungan hukum negara, maka pekerja domestik rentan terhadap berbagai bentuk perlakuan kekerasan bahkan sampai mengakibatkan kematian. Kekerasan fisik sering dilaporkan terjadi di kalangan pekerja domestik. Demikian pula kekerasan verbal seperti teriakan dan cacian dengan bahasa hinaan terhadap nasionaliti atau ras dari pekerja domestik, pelecehan seksual dan siksaan juga terjadi.

\section{Perlindungan Hukum bagi Pekerja Migran}

Sebagaimana diketahui di Indonesia sudah ada payung hukum yang menjamin keadilan bagi setiap orang, untuk memperoleh hak-hak dasarnya dalam bekerja. Akan tetapi tidak ada undang-undang khusus yang mengatur keberadaan pekerja domestik, apalagi yang bekerja di luar negeri.

Peraturan perundang-undangan yang sudah ada khususnya UU RI No.39 tahun 2004 (UU PPTKILN) tidak cukup memadai dalam memberi perlindungan dan akses keadilan. ${ }^{24}$ Substansi hukumnya tidak jelas dalam banyak hal menimbulkan kebingungan dalam implementasinya. Di antara ketidakjelasan itu adalah juga ketiadaan sanksi bagi para pihak yang melanggarnya. Ketidakjelasan pengaturan itu disebabkan juga landasan filsafat untuk memberi perlindungan secara mendasar memang tidak nampak.

\section{Problem hukum}

Undang-undang RI Nomor 39 Tahun 2004 (UU PPTKILN) menjadi acuan, sebagai satu-satunya undang-undang khusus tentang pekerja migran, akan tetapi didalamnya tidak meliputi pengaturan pekerja migran domestik.

Persoalan pekerja migran yang bersumber pada instrumen hukum tentang pekerja migran Indonesia tidak sedikit mendapat sorotan dari banyak lembaga swadaya masyarakat, organisasi kemasyarakat dan Komisi Nasional Perempuan, namun permasalahan terlalu rumit dan luas untuk diatasi. Hal ini menun-

\footnotetext{
${ }^{23}$ Kompas, Kantong TKI di Lumbung Padi, 27 Desember 2011, h. 19

${ }^{24}$ KOPBUMI, op.cit, h.12
}

jukkan betapa besarnya tarik menarik kepentingan antar pihak. Betapa besarnya posisi tawar dari negara yang berkepentingan mendapatkan devisa dari sektor migrasi dan pihak pengambil keuntungan, khususnya perusahaan pengerah tenaga kerja di Indonesia maupun di negara tujuan.

Para aktivis dari gerakan advokasi pekerja migran, berpendapat bahwa Undang-Undang RI Nomor 39 Tahun 2004 (UU PPTKILN) menempatkan pekerja migran sesungguhnya merupakan produk hukum yang tidak berpihak kepada pekerja migran. Prinsip privatisasi atau swastanisasi mewarnai pembentukan undang-undang ini lebih mengusung semangatbisnis yaitu kepentingan perusahaan pengerah tenaga kerja daripada memberikan perlindungan yang memadai bagi pekerja migran. Dari keseluruhan 109 pasal dan 16 bab, hanya terdapat 8 pasal (Pasal 77 sampai 84) yang mengatur mengenai perlindungan dibandingkan 86 pasal mengenai mekanisme penempatan pekerja migran.

Pada level kebijakan maupun implementasi, UU PPTKILN lebih memposisikan pekerja migran sebagai komoditas dalam bentuk pengadaan tenaga murah bagi kepentingan pengusaha pengerah dan bukan perlindungan bagi pekerja migran.

Pasal-pasal mengenai perlindungan selain tidak jelas, juga sangat tidak cukup untuk memproteksi hak dan kepentingan pekerja migran Indonesia. Meskipun dalam Pasal 77 ayat (2) disebutkan migran Indonesia "Perlindungan sebagaimana dimaksud ayat (1) dilaksanakan mulai dari pra penempatan, masa penempatan sampai dengan purna penempatan", namun dalam pasal-pasal berikutnya (Pasal 28 sampai Pasal 84) semuanya hanya bermakna perlindungan selama masa penempatan di negara tujuan. Padahal undangundang ini tidak mampu menjangkau pekerja domestik Indonesia di rumah majikannya di luar negeri.

Salah satu implikasi dari pengamatan pada penempatan daripada perlindungan adalah tidak terakomodasinya perlindungan bagi pekerja migran yang tidak berdokumen (pekerja migran undocumented). Mereka dianggap tidak perlu memperoleh proteksi karena berada di luar kerangka penempatan. Hal itu juga berlaku bagi pekerja migran yang berangkat secara mandiri.

Peran rekrutmen dan penempatan pekerja migran Indonesia di luar negeri sama sekali dilakukan oleh perusahaan swasta. Peran pemerintah adalah mengawasi melalui skema perijinan. Padahal dalam per- 
syaratan perijinan itulah justru terkandung berbagai permasalahan. Beratnya syarat permodalan dianggap sangat memberatkan oleh perusahaan.

Beban menanggung jumlah biaya dan ongkos lain yang tidak diketahui peruntukannya oleh pekerja migran Indonesia, merupakan bentuk eksploitasi yang berat bahkan sebelum mereka bekerja. Hal ini berimplikasi terhadap terjadinya mirip kerja paksa karena beban tersebut sering berbentuk jeratan hutang. Implikasi kedua adalah ketika hukum menentukan biaya maka potensial mendorong pekerja migran untuk menghindari sistem formal dan ini merupakan salah satu sebabnya munculnya pekerja migran tanpa dokumen.

Menurut Pasal 8 UU Penempatan dan Perlindungan Pekerja Migran "setiap calon pekerja berhak atas salinan kontrak antara dirinya dan majikan di luar negeri”. Dalam kontrak tersebut harus dicantumkan hak-hak pekerja. Dan dalam Pasal 55 undang-undang tersebut dinyatakan kontrak harus ditandatangani sebelum keberangkatan, namun mandat itu dalam praktiknya sering diterjemahkan sebagai calon pekerja migran diminta menadatangani kontrak di tempat.

\section{Pengetahuan dan Pemahaman Hukum}

Pengetahuan dan pemahaman hukum menjadi unsur penting bagi jaminan akses keadilan. Para pekerja migran, terlebih perempuan pekerja migran domestik, seharusnya mengetahui hak-hak dasarnya sebagai pencari kerja yang dilindungi oleh hukum. Demikian pula seharusnya mereka mengetahui bahwa hukum menjamin pemenuhan hak-haknya sebagai manusia untuk dapat bekerja dan mendapat upah yang layak dalam situasi kerja yang terjamin keselamatan dan kesehatannya, terbebas dari kekerasan, sesuai dengan standar hak asasi manusia universal. Mereka seharusnya paham bahwa segala sesuatu berkenaan dengan pemenuhan hak-hak dasarnya, mesti dibuat dalam kontrak tertulis dan disepakati bersama.

Pemahaman dan pengetahuan yang berkaitan dengan perlindungan hak-hak dasarnya terletak pada tahap pra penempatan/pemberangkatan, ketika mereka mendapatkan sejumlah latihan dan pendidikan.

Pendidikan dan pelatihan kerja merupakan syarat mutlak dan prioritas utama yang harus ditempuh oleh semua calon pekerja migran yang hendak bekerja di luar negeri agar mereka siap menghadapi berbagai kemungkinan yang terjadi ketika mereka bekerja. Tingkat kesiapan para calon pekerja migran tidak hanya menentukan keberhasilan kerja mereka di luar negeri tetapi juga berperan besar menjamin keselamatan dari mereka selama bekerja.

Jika melihat aturan mengenai pendidikan dan pelatihan kerja yang diatur dalam undang-undang penempatan dan perlindungan sepertinya pemerintah sangat serius mempersiapkan para calon pekerja migran dengan bekal pengetahuan dan pemahaman, bahkan ada sertifikasi yang memungkinkan mereka menjadi pekerja professional dan terhindar dari perlakuan diskriminatif dan kekerasan di tempat kerja, akan tetapi ternyata aturan tersebut memiliki kelehaman.

Kelemahan pertama undang-undang menempatkan perusahaan pengerah tenaga kerja sebagai pemegang kendali pendidikan dan pelatihan bagi para calon pekerja migran sebagaimana diatur dalam $\mathrm{Pa}-$ sal 43 ayat (1). ${ }^{25} \mathrm{Hal}$ ini dapat menimbulkan konflik kepentingan dalam perusahaan pengerah. Kualitas pendidikan dan pelatihan kerja bagi calon pekerja migran bisa saja dikalahkan oleh orientasi memberangkatkan calon pekerja migran yang tidak lulus dalam uji kompetensi kerja atau mempekerjakan calon pekerja migran yang sedang mengikuti pendidikan dan pelatihan. ${ }^{26}$

\section{Identitas hukum}

Dimilikinya identitas hukum oleh setiap orang merupakan hak dasar, yang tidak bisa dicabut atau dilanggar oleh siapapun, namun dalam kenyataannya banyak sekali pekerja migran yang tidak memiliki akses untuk memperoleh dengan cara yang tepat dan menyimpan dokumen identitas dirinya. Pemalsuan dokumen, pemalsuan data dokumen, dan penahanan paspor oleh majikan atau jasa pengerah tenaga kerja adalah peristiwa yang sering dijumpai.

Persoalan identitas hukum terkait dengan tahap pemberian informasi kepada calon pekerja migran pada tahap perekrutan. Dalam tahap ini perusahaan pengerah tenaga kerja memegang peranan penting, sedangkan peran pemerintah hanyalah memberikan persetujuan terhadap informasi yang akan diberikan

\footnotetext{
${ }^{25}$ Pasal 42 ayat (1) No.39 tahun 2004: Pendidikan dan pelatihan kerja dilaksanakan oleh pelaksana penempatan tenaga kerja swasta atau lembaga pelatihan kerja yang telah memenuhi persyaratan.

26 Sulistyowati Irianto, Perempuan dan Hukum, 2006 Jakarta: Yayasan Obor, dan Program Studi Kajian Wanita Universitas Indonesia, 2006, h.315.
} 
oleh perusahaan tersebut. Di sini ada penyerahan tentang tanggung jawab dari pemerintah kepada perusahaan pengerah tenaga kerja.

Pada kenyataan di lapangan pihak yang menjalankan tugas untuk memberikan informasi atas nama perusahaan pengerah tenaga kerja adalah para sponsor yang sebenarnya bukan pegawai tetap dari perusahaan bahkan kebanyakan sponsor bekerja tidak hanya untuk satu perusahaan. Para sponsor ini tidak menyampaikan informasi yang sangat dibutuhkan kepada para calon pekerja migran bahkan mereka mempunyai kepentingan untuk menyembunyikan informasi yang benar dan lengkap agar memperoleh keuntungan dari sisa uang pembiayaan yang diberikan oleh perusahaan. Untuk menarik minat para calon pekerja migran, mereka lebih banyak memberikan janji dan gambaran-gambaran yang indah tentang bekerja di luar negeri daripada memberikan informasi mengenai risiko bekerja yang harus dihadapi oleh para calon pekerja migran.

\section{Perubahan Sosial}

\section{Status dan peran perampuan migran}

Perempuan kelas bawah merupakan kelompok yang berada dalam kondisi kurang menguntungkan, berpendidikan rendah, tidak mempunyai pengetahuan yang cukup, tanpa keterampilan dan berada di sektor-sektor marginal. Dengan kebutuhan hidup yang makin meningkat, beban kaum perempuan semakin berat, mereka harus dapat menghidupi dirinya sendiri mempertahankan kelangsungan hidup keluarga. ${ }^{27}$

Dalam masyarakat selalu ada dikotomi pembagian kerja produksi (menghasilkan sesuatu) dan reproduksi (secara harafiah menggantikan apa yang telah habis atau hilang) untuk kelestarian sistem atau struktur sosial yang bersangkutan. Penggunaan kedua konsep ini mulai dilihat keterbatasannya, terutama oleh pemerhati masalah sosial, ketika kegiatan yang tidak langsung menghasilkan sesuatu seperti memasak, menjahit, mencuci juga termasuk kerja. Pekerjaan produksi tidak dapat dilakukan bila pekerja mendasar dalam rumah tangga tersebut tidak ditangani. Sementara itu, kerja reproduksi juga tidak hanya menyangkut apa yang terjadi dalam rumah tangga misalnya kegiatan yang menjamin kelestarian

\footnotetext{
${ }^{27}$ Tri Marhanei P Astuti, Gerakan Tandingan Perempuan, Jakarta : Program Studi Kajian Wanita Universitas Indonesia, 2000, h. 414 .
}

struktur sosial yang ada seperti upacara-upacara siklus hidup atau kegiatan sosial dalam komunitas.

Konsekuensi dari adanya pembedaan kerja produksi dan reproduksi ini adalah juga dikotomi tentang ranah publik dan ranah domestik. Ranah publik selalu diasosiasikan sebagai kerja di luar rumah dan ranah domestik adalah kerja di dalam rumah. Implikasi dari kerja publik dan domestik ini adalah adanya pembagian peran antara laki-laki dan perempuan. Laki-laki selalu diidentikkan dengan kerja di luar rumah, mencari nafkah untuk keluarga, sementara perempuan bekerja di dalam rumah untuk urusanurusan rumah tangga. Meskipun seringkali perempuan itu bekerja di sekitar rumah dan menghasilkan upah untuk menyambung hidup keluarganya, hal ini seringkali tidak dihargai, karena adanya kesepakatan umum bahwa tempat perempuan adalah di rumah. Akibat lebih lanjut ketika perempuan mulai memasuki ranah publik, dia tetap dianggap sebagai seorang ibu rumah tangga bukan sebagai pekerja. ${ }^{28}$

Migrasi yang dilakukan perempuan jauh ke luar dari tempatnya tentu saja membawa beberapa implikasi tertentu. Pertama pilihan perempuan untuk bermigrasi ke suatu tempat yang melibatkan penyebaran batar kultural dan negara membawa konsekuensi sosial, ekonomi, psikologi dan politis ada beberapa perubahan dalam pola hidupnya. Bagi yang belum berkeluarga akan terjadi perubahan dan pergeseran status dan posisi, begitu juga bagi perempuan yang sudah berkeluarga. Ketika bermigrasinya kaum perempuan ke luar negeri tentu saja menimbulkan pergeseran-pergeseran dalam kehidupan rumah tangga mereka, baik dalam pola hidup, pola kerja dan peran yang selama ini mereka jalani.

Karena perempuan yang dulu diidealkan menjadi "penguasa rumah tangga" dan tinggal di dalam rumah karena kebutuhan karena kemajuan zaman kini telah berani melangkah ke luar rumah untuk bekerja mencari nafkah. Secara umum ada tiga faktor utama yang mendorong pekerja perempuan bermigrasi ke luar negeri. Pertama, kondisi ekonomi yang miskin, sehingga menjadi pembantu rumah tangga di luar negeri memungkinkan mereka mendapat gaji yang besar. Bekerja ke luar negeri menjadi pilihan karena kesempatan kerja diluar pertanian terbatas. Kedua, keberhasilan ekonomis tetangga yang sudah bermigrasi mendorong tetangga lainnya untuk bermigrasi. $\mathrm{Ru}-$

\footnotetext{
${ }^{28}$ Irwan Abdullah, Sanggan Peran Gender, Yogyakarta: Pustaka Pelajar, 1997, h..45.
} 
mah yang dibangun dengan tembok di desa hampir selalu terkait dengan remitan yang diperoleh oleh salah satu atau lebih anggota keluarga yang bekerja di luar negeri. Ketika kemudahan pengurusan ijin dan syarat-syarat lain juga menjadi salah satu pemicu keberanian kaum perempuan untuk bermigrasi. Cerita tentang "kekejaman majikan" di luar negeri tampaknya tidak banyak berpengaruh dalam pengambilan keputusan untuk bekerja ke luar negeri.

Berbagai konsekuensi kemudian harus ia tanggung. Pertama, beban perempuan sebenarnya tidak menjadi berkurang dengan pilihan untuk bekerja diluar rumah, bahkan menjadi semakin berat bebannya, yaitu tugas publik dan tugas domestik yang harus dijalankan bersama-sama. Kedua, perempuan harus berani bersaing dengan laki-laki (dan juga perempuan) di pasar kerja yang telah terlanjur didominasi oleh laki-laki. Ketiga, beban di tempat kerja yang dialami oleh perempuan sampai kenyataannya bahwa rekan kerjanya yang laki-laki tidak menganggap dia sebagai teman seprofesi melainkan "sosok lain: yang kurang pantas berada dalam dunia kerja yang dianggap "ruang laki-laki".

Praktik-praktik sosial yang merugikan perempuan ini terus berlanjut, didukung oleh struktur dan pranata sosial yang ikut melanggengkannya. Meskipun pada era globalisasi ini perempuan aktif dalam proses produksi dan kurang menghadapi hambatan kultural dan sosial yang berarti dalam melakukan aktivitas di luar rumah atau kegiatan non domestik, namun status dan posisi perempuan masih dilingkupi oleh nilai-nilai yang patriarki yang memihak kepada laki-laki.

\section{Beban migrasi bagi pekerja perempuan}

Perginya seorang perempuan ke luar negeri sesungguhnya telah merupakan beban tersendiri bagi kaum perempuan. Ia memikul beban moral yang sangat besar karena keberangkatannya bertujuan untuk meningkatkan ekonomi keluarga. Di sisi lain kepergian ke luar negeri merupakan cara melakukan pembebasan terhadap ikatan-ikatan status dan peran yang secara tradisional didefinisikan. Dengan pergi ke luar negeri ia dapat "meninggalkan" segala kewajiban yang melekat pada dirinya sebagai seorang perempuan. Namun demikian di luar negeri ia menghadapi masalah, masuk ke dalam suatu dunia kerja dengan kultural dan psikologis.

Beban kultural dirasakan saat etika yang diterapkan di tempat kerja mereka juga berbeda dengan norma-norma yang berlaku di negara asal. Sebagai pekerja rumah tangga, migran perempuan ditempatkan pada strata yang rendah dalam rangkaian hubungan sosial yang didiskriminatif atau berbagai bentuk eksploitasi yang biasa terjadi di tempat kerja. Citra Indonesia yang begituburuk akhir-akhir ini di Malaysia misalnya harus ditanggung oleh kaum perempuan migran dalam bentuk kecurigaan dan perlakuan-perlakuan diskriminatif. Persoalan ini sekaligus menjadi beban psikologis bagi perempuan yang berada jauh di kampung dan orang-orang dekat. Dalam kasus tertentu keberadaannya di luar negeri dijadikan sasaran penipuan terkait dengan uang yang dikirim atau harga yang dimiliki, sehingga jerih payah perempuan tidak selalu memiliki konsekuensi positif bagi perempuan itu sendiri. Akhirnya mereka tetap tinggal dalam perangkap sistem dan struktur sosial yang ada.

Kecenderungan perempuan meninggalkan rumah (bekerja di luar desa atau pergi ke luar negeri) dapat dilihat sebagai suatu tanda adanya proses dekonstruksi terhadap realita sosial yang baku. Dekonstruksi ini kemudian menghasilkan suatu proses rekonstruksi yang merupakan proses rekonseptualisasi dan redefinisi kaum perempuan. Fenomena ini tidak saja mewujudkan "gugatan" terhadap ideologi feminisim tetapi juga menunjukkan bahwa sebenarnya pekerja migran perempuan dapat digolongkan sebagai agen transformasi sosial atau perubahan sosial, meskipun mereka tidak menyadarinya dan seringkali tidak pula disadari oleh orang lain.

\section{Migrasi global}

Bermigrasi untuk mencari penghidupan yang lebih baik merupakan hak dari setiap orang. Saat ini jutaan orang menjadi bagian dari gelombang migrasi global yang sangat dinamis. Migrasi telah menghebohkan dunia kehilangan batas-batas negara hukum dan bahkan budaya. Batas negara hanyalah batas administratif dan hukum kehilangan batas yuridiksi substantifnya.

Migrasi telah menghebohkan pertemuan antara kebudayaan, yang menghasilkan kebudayaan masal, kebudaya global. Di seluruh dunia dapat ditemui adanya unsur kebudayaan global yang sangat terdukung oleh pertukaran uang dan jasa yang luar biasa kuatnya dan teknologi informasi yang begitu agresif. Kebudayaan global hidup berdampingan dengan kebudayaan tradisional. 
Ada banyak sebab mengapa orang melakukan migrasi, yang terbesar adalah karena pekerjaan dalam rangka mencari penghidupan yang lebih layak. Migrasi karena pekerjaan merupakan situasi yang paling umum karena dapat dijumpai di berbagai belahan dunia. Masyarakat dari kelompok paling miskin di negara berkembang bermigrasi ke negara-negara yang lebih kaya. Pada umumnya mereka mengisi lowongan pekerjaan rendah, dengan upah rendah dan kondisi kerja yang buruk karena ketiadaan perlindungan hukum. Kebanyakan dari pekerjaan migran yang mengisi pekerjaan rendah dan dalam skala masif ini adalah para perempuan.

Di antara berbagai fenomena migrasi dapat dijumpai bahwa migrasi sangat berwajah perempuan. Pasar dan ekonomi global berkembang pesat secara langsung berdampak terhadap terjadinya perubahan sosio kultural masyarakat. Khususnya masyarakat di negara-negara yang lebih sejahtera, membutuhkan lebih banyak tenaga kerja murah untuk menggantikan peran-peran mereka dalam lapangan pekerjaan rendahan. Diantaranya ialah lapangan pekerjaan ranah domestik.

\section{Kesimpulan}

Migrasi internasional terjadi akibat meningkatnya populasi jumlah penduduk yang tidak diimbangi dengan tumbuhnya peluang kerja sehingga menyebabkan banyaknya angkatan kerja produktif yang tidak mempunyai pekerjaan (unemployment). Meningkatnya jumlah angkatan kerja di satu sisi dan menyempitnya peluang kerja di sisi lain secara bersamaan merupakan salah satu faktor yang menyebabkan orang melakukan migrasi. Dalam hal ini faktor ekonomi dikatakan sebagai salah satu faktor penyebab terjadinya migrasi. Migrasi internasional yang disebabkan adanya ketimpangan antara pembangunan ekonomi di kawasan/negara maju dibandingkan dengan negara berkembang. Undang-Undang No.39 tahun 2004 tentang Penempatan dan Perlindungan Tenaga Kerja Indonesia di Luar Negeri yang menjadi acuan sebagai satu-satunya undang-undang khsuus tentang pekerja migran tidak memberikan jaminan perlindungan bagi pekerja migran. UU ini justru memposisikan pekerja migran sebagai komoditas, sehingga tidak mengubah kondisi pekerja migran. Kerja rumah tangga, domestik, distrukturkan secara sosial dan budaya sebagai pekerjaan perempuan, pekerjaan yang rendah, kotor, berbahaya dan tidak layak disebut sebagai pekerjaan setara dengan pekerjaan formal di pasar kerja. Keberadaan pekerjaan rumah tangga "tidak perlu diatur" terefleksi dalam hukum Indonesia tentang pekerja migran. Hukum merefleksi konteks sosial budaya dan politik dimana hukum itu berada

\section{Saran}

Menjamin adanya terobosan politik untuk mengatasi hubungan tidak setara antara negara tujuan dan negara penerima agar mendapat keleluasaan yang lebih dalam memberi perlindungan kepada para perempuan pekerja domestik. Merevisi UU No.39 tahun 2004 tentang Penempatan dan Perlindungan Tenaga Kerja di Luar Negeri dengan perspektif perlindungan hak asasi manusia khususnya hak-hak pekerja. Melakukan pemberdayaan terhadap pekerja migran perempuan dengan jalan memberikan pendidikan politik dan hukukm untuk membangun kemandirian pekerja migran perempuan. Pemberdayaan ini harus merupakan sinergi antara pemerintah dan pekerja migran perempuan. Hal ini dimaksudkan agar terjadi pemahaman yang sama antara kedua belah pihak dalam meningkatkan kualitas keterampilan dan mekanisme penempatan.

\section{Daftar Pustaka}

\section{Buku}

Ana Sabhana Azny, Negara Dan Buruh Migran Perempuan, Jakarta:Yayasan Pustaka Obor Indonesia, 2012.

Guy Standing, Global Labour Flexibility, Seeling Distributive Justice,London: Macmillan Press Ltd, 1999.

Henrieta Moore, Feminism and Antropology, University of Minnesota, 1998.

Irwan Abdullah, Sangkan Peran Gender, Yogyakarta: Pustaka Pelajar,1997

KOPBUMI, Legal Analisis UU RI No.39 Tahun 2004. Jakarta, 2005

Kurnia Novianti, Analisis Trend dan Dampak Pengiriman TKI: Kasus Dua Desa di Lombok Timur, Nusa Tenggara Barat, Jurnal LIPI vol. V No.1, Jakarta, 2019.

L.M. Gandhi Lapian, Disiplin Hukum yang Mewujudkan Kesetaraan dan Keadilan Gender,Jakarta: Pustaka Obor Indonesia, 2012. 
Rachmad Syafaat, Dagang Manusia: Kajian Traffiching terhadap Perempuan dan Anak, Yogyakarta: Lappera Pustaka Utama, 2003.

Ridjal, Dinamika Gerakan Perempuan di Indonesia,

Yogyakarta: Tiara Wacana, 1993.

Rosaldo Renato dan Inda J, The Antropology of Glo- balisazations a Reader, Oxford: Blackwell Publishers, 2002.

Sulistyowati Irianto, Akses Keadilan dan Migrasi Global, Jakarta: Yayasan Pustaka Obor Indo- nesia, 2011

-------------, Perempuan dan Hukum, Jakarta: Yaya- san Obor dan Program Studi Kajian Wanita Universitas Indonesia, 2006.

Tri Marheni P Astuti, Gerakan Tandingan Perem- puan, Jakarta: Program Studi Kajian Wanita Universitas Indonesia, 2000

Yesmil Anwar dan Adang, Pengantar Sosiologi Hu- kum, Jakarta: Grasindo, 2008

\section{Jurnal, Koran, Internet}

http://nasional.vivanews.com/news/read/6of 973-Si- ti Hajar Senasib dengan Nirmala Bonat diakses pada tanggal 21 Februari 211

Kompas, Kantong TKI di Lumbung Padi, 27 Desem- ber 2011.

Program Studi Kajian Wanita, Universitas Indonesia, Perempuan dan Pemberdayaan, Jakarta, 1997

\section{Peraturan Perundang-undangan}

Undang-undang RI Nomor 39 Tahun 2004 Tentang Penempatan dan Perlindungan Tenaga Kerja Indonesia 